\title{
Alterations in Cytotoxic and Helper T Cell Function After Infection of T Cell Clones with Human T Cell Leukemia Virus, Type I
}

\author{
Robert Yarchoan, * Hong-Guang Guo,‡ Marvin Reitz, Jr.,‡ Annette Maluish,\$ Hiroaki Mitsuya,“ and Samuel Broder* \\ *Clinical Oncology Program and $\ddagger$ Laboratory of Tumor Cell Biology, National Cancer Institute, National Institutes of Health (NIH), \\ Bethesda, Maryland 20892, and §Frederick Cancer Research Center, Frederick, Maryland 21701
}

\begin{abstract}
HTLV-I is a transforming human retrovirus that is an etiologic agent of adult $T$ cell leukemia/lymphoma. To investigate the effects of this virus on $\mathrm{T}$ cell functions, two $\mathrm{OKT3}^{+}, \mathrm{OKT4}^{+}$, OKT8- cytotoxic clones (8.7 and 8.8) specific for allogeneic cells bearing DPw2, a class II histocompatibility antigen, were studied before and after infection with HTLV-I. The clones retained cytotoxic function for up to $70 \mathrm{~d}$ after exposure to HTLV-I, even without subsequent antigenic stimulation, but then lost their cytotoxic activity. Prior to infection with HTLV-I, clone 8.8 also lysed OKT3 hybridoma cells; after infection, cytotoxic activity against these OKT3-antibody bearing cells was lost in parallel with the loss of activity against DPw2-bearing target cells. In addition, expression of T3 surface antigen by HTLV-I-infected 8.8 cells was decreased at a time when they lost their cytotoxic activity, possibly contributing to the loss of cytotoxic function. Finally, clone 8.8 could provide help for nonspecific IgG production by autologous $B$ cells when stimulated with irradiated DPw2-bearing non-T cells. After infection with HTLV-I, this helper function became independent of DPw2-stimulation and persisted even when the cytotoxic activity was lost. An OKT4 ${ }^{+}$ $T$ cell clone thus could simultaneously manifest both cytotoxic and helper $\mathrm{T}$ cell activities, and these activities were differentially affected after HTLV-I infection.
\end{abstract}

\section{Introduction}

Human T cell leukemia virus, type I (HTLV-I), ${ }^{1}$ is an exogenous human retrovirus that is tropic for $\mathrm{T}$ cells bearing the OKT4 surface phenotype although other cell types can be infected (13). HTLV-I was first isolated from a patient with adult $T$ cell leukemia/lymphoma (ATL) in the United States (1) and has been shown to be an etiologic agent of this disease in several parts of the world $(2,4,5)$. In addition, HTLV-I infection has been associated with impairment of immune function; patients with ATL often develop opportunistic infections with agents such as Pneumocystis carinii even before they receive immunosuppressive chemotherapy (5), and otherwise asymptomatic

Presented in part at the National Meeting of the American Federation for Clinical Research, Washington, DC, May 1985.

Address all correspondence to Dr. Robert Yarchoan, Building 10, Room 6B15, NIH, Bethesda, MD 20892.

Received for publication 29 July 1985.

1. Abbreviations used in this paper: ATL, adult T cell leukemia/lymphoma; Con A, concanavalin A; EBV, Epstein-Barr virus; E:T, effector to target ratio; FCS, fetal calf serum; HTLV-I, human T cell leukemia virus, type I; IL-2, interleukin 2; LOR, long open reading frame; PBMC, peripheral blood mononuclear cells; PWM, pokeweed mitogen.

The Journal of Clinical Investigation, Inc.

Volume 77, May 1986, 1466-1473 persons infected with HTLV-I have been shown to have an increased incidence of infectious diseases (6).

The behavior of HTLV-I in tissue culture mirrors these clinical manifestations. T cells infected with HTLV-I become transformed with increased expression of interleukin 2 (IL-2) receptors and a reduction or elimination in their requirement for interleukin $2(3,7)$. In addition, HTLV-I has been shown to induce alterations in specific $T$ cell functions. After infection with HTLV-I, antigen-specific clones have been observed to lose their requirement for antigen presentation by accessory cells with shared histocompatibility antigens in order to proliferate or to provide help for immunoglobulin (Ig) production $(8,9)$. Cytotoxic clones have been shown to lose their cytotoxic function (9). Finally, T cell lines infected with HTLV-I have been shown to constitutively secrete a variety of lymphokines $(10,11)$ and to proliferate when stimulated with cells bearing any class II histocompatibility antigen (12).

The relationship between these various alterations in $\mathrm{T}$ cell function is at this point not clear, and the intracellular mechanisms responsible for them are largely unknown. In this article, we show that a class II alloantigen-specific $\mathrm{T}$ cell clone with both cytotoxic activity and helper function for $\mathrm{Ig}$ production retains its cytotoxic function for $\sim 60-70 \mathrm{~d}$ after infection with HTLVI but then loses it, and that the loss of cytotoxic function by this clone is associated with a decreased expression of T3 surface antigen. Nonspecific helper activity for Ig production, however, persisted following HTLV-I infection and became independent of antigenic stimulation. These results indicate that HTLV-I infection can simultaneously induce a variety of changes in $T$ cell function; these changes likely result from a complex series of interactions between the viral gene products and intracellular regulatory mechanisms. These changes in $\mathrm{T}$ cell function may contribute to the immunosuppression seen with HTLV-I infection, and this immunosuppression may conceivably be permissive for the development of ATL.

\section{Methods}

Generation of DPw2-specific cytotoxic $T$ cell clones. Two cytotoxic T cell clones, 8.7 and 8.8, specific for DPw2 (formerly SP2) alloantigen were generated as previously described (13) and were generously provided for these studies by William E. Biddison (National Institute of Neurological, Communicative Disorders, and Stroke, Bethesda, MD) and J. Stephen Shaw (National Cancer Institute, Bethesda, MD). Briefly, a bulk cytotoxic effector population was generated in a secondary mixed lymphocyte reaction between peripheral blood mononuclear cells (PBMC) from donor F2 and a stimulator donor who was matched for HLA-A, B, -C, -D, -DR, and -DQ but mismatched for DP. These effector cells were cloned at 0.3 cells per well in the presence of irradiated stimulator PBMC and expanded by repeated stimulation. The clones were originally maintained in RPMI 1640 medium (Gibco, Grand Island, NY) supplemented with penicillin $(100 \mathrm{U} / \mathrm{ml})$, streptomycin $(100 \mu \mathrm{g} / \mathrm{ml}), 10 \% \mathrm{hu}-$ man plasma, and $10 \%$ phytohemagglutinin-stimulated PBMC supernatant as a source of IL-2 (13), but later transferred to media containing 
$10 \%$ fetal calf serum (FCS) (Gibco) instead of human plasma and $15 \%$ mitogen-depleted IL-2 (Cellular Products, Buffalo, NY). Clones 8.7 and 8.8 were $\mathrm{OKT}^{+}, \mathrm{OKT}^{+}$, and $\mathrm{OKT}^{-}$, and had specificity against cells bearing DPw2 $(13,14)$. Aliquots of the clones were sometimes frozen, stored in liquid nitrogen, and subsequently thawed.

Additional cell lines. MJ-tumor is an HTLV-I producing neoplastic $T$ cell line derived from patient $M J$ with acute $T$ cell leukemia/lymphoma and now propagated in the absence of exogenous IL-2 (9). M16B, Y2B, H9B, F2B, FB1 1 B, and M14B are B cell lines derived by transformation with the B95-8 strain of Epstein-Barr virus (EBV) from donors M16, Y2, etc., respectively (13). K562 is a natural killer cell-sensitive erythroid cell line. The OKT3 hybridoma (producing anti-T3 antibody) was obtained from the American Type Tissue Collection, Bethesda, MD.

Cytotoxicity assay. A 4- ${ }^{51} \mathrm{Cr}$-release assay was carried out in roundbottomed microtiter plates (Linbro Chemical Co., Hamden, CT) as previously described (13) with the modification that 5,000 target cells were used in each well. In certain experiments, lectin-mediated cytotoxic function was assessed in the presence of $20 \mu \mathrm{g} / \mathrm{ml}$ of concanavalin A (Con A) (Calbiochem-Behring Corp., Div. of American Hoechst Corp., La Jolla, CA). The percentage of specific ${ }^{51} \mathrm{Cr}$ release at a given effector: target (E:T) ratio was calculated as [(release with effector cells - spontaneous release)/(maximum release - spontaneous release)] $\times 100 \%$. Spontaneous release was $<30 \%$ of the maximum release for all target cells.

IgG biosynthesis assay. The ability of $\mathrm{T}$ cell lines to provide helper or suppressor activity for polyclonal IgG synthesis by autologous (F2) B cells was investigated using a microplate assay system. PBMC were obtained from donors $\mathrm{F} 2$ and $\mathrm{Y} 2$ by Ficoll-Hypaque centrifugation. $\mathrm{T}$ cell enriched and depleted populations were separated by rosetting with 2aminoethylisothioronium bromide-treated sheep red blood cells followed by separation of rosette-forming cells on Ficoll-Hypaque gradients (15); the $T$ cell-enriched fraction are referred to as " $T$ cells" and the $B$ cellenriched fraction as "B cells." These $B$ cells, $T$ cells, and the cell lines to be assayed were depleted of cytophilic Ig by two centrifugations through FCS. The ability of 8.8 cells to provide help for IgG production by autologous F2 B cells was assessed by culturing $5 \times 10^{4} \mathrm{~F} 2$ B cells with 5 $\times 10^{4} 8.8$ cells (HTLV-I uninfected or infected) in the presence or absence of $5 \times 10^{4}$ irradiated $(3,000 \mathrm{rad}) \mathrm{Y} 2\left(\mathrm{DPw} 2^{+}\right) \mathrm{B}$ cells as a source of DPw2 antigen. The ability of 8.8 cells to suppress IgG production was assessed by culturing $5 \times 10^{4} 8.8$ cells (HTLV-I uninfected or infected) with 5 $\times 10^{4} \mathrm{~F} 2 \mathrm{~B}$ cells and $1 \times 10^{5}$ irradiated $(2,000 \mathrm{rad}) \mathrm{F} 2 \mathrm{~T}$ cells in cultures stimulated with pokeweed mitogen (PWM) (Gibco) 1:100 (vol/vol) final dilution. All cultures were done in triplicate in 96-well round-bottomed plates (Costar, Data Packaging, Cambridge, MA) in $0.2 \mathrm{ml}$ of RPMI 1640 media supplemented with $50 \mathrm{U} / \mathrm{ml}$ penicillin, $50 \mu \mathrm{g} / \mathrm{ml}$ streptomycin, $4 \mathrm{mM}$ L-glutamine, and 10\% FCS (all from Gibco). Cumulative secretion of IgG over $10 \mathrm{~d}$ in culture was measured by a sandwich enzymelinked immunosorbent assay (ELISA) as previously described (16). Geometric means and standard deviations were calculated for the triplicate cultures.

Analysis of cellular antigens. The expression of surface antigens on the infected and uninfected $\mathrm{T}$ cell clones was assessed by reactivity with the fluorescein-conjugated monoclonal antibodies OKT3, OKT4, OKT8 (Ortho Pharmaceutical, Raritan, NJ), anti-Leu 8, and anti-IL-2 receptor (IL-2 R) (Becton-Dickinson \& Co., Mountain View, CA) by flow cytometry. Paired samples were analyzed on an Ortho cytofluorograf system 30-H with a 2150 computer (Ortho Diagnostic Systems, Inc., Westwood, MA). This instrument has the capability of simultaneously measuring forward and right-angle scatter and detecting red and green fluorescence using a single Lexel argon laser $(488 \mathrm{~nm})$. Dead cells were excluded from analysis by red fluorescence (i.e., staining of the DNA in dead cells by propidium iodide), and viable lymphocytes were selected using a combination of forward and right-angle scatter.

The expression of HTLV-I gag proteins p19 and p24 was determined by immunofluorescent microscopy as previously described $(10,17)$. HLA serotyping of the lines was done by Dr. Richard Aster of the Blood Center of Southeastern Wisconsin under National Cancer Institute contract NOI-CB-33935.
Analysis of HTLV-I proviral sequences. High molecular weight DNA prepared from clone 8.8 following exposure to $\mathrm{MJ}$ tumor cells or from an EBV-transformed B cell line was digested for $16 \mathrm{~h}$ at $37^{\circ} \mathrm{C}$ with Eco RI (Boehringer Mannheim Biochemicals, Indianapolis, IN) or Bam HI (International Biotechnologies, New Haven, CT) in buffers specified by the manufacturers. These digests ( $30 \mu \mathrm{g} / \mathrm{lane}$ ) were subjected to electrophoresis overnight at $40 \mathrm{~V}$ in $\mathbf{0 . 8 \%}$ agarose, transferred to nitrocellulose, and analyzed by hybridization with a ${ }^{32} \mathrm{P}$-nick-translated probe, $\mathrm{pCH}-1$, which contained the pol, env, and $p X$ sequences of HTLV-I as described (18). Hind III digested fragments of $\lambda$-phage DNA were simultaneously run as size markers.

\section{Results}

Infection of $T$ cell clones with HTLV-I. Cells from T cell clones 8.7 and 8.8 taken $\sim 28 \mathrm{~d}$ after cloning were infected with HTLVI by co-culturing $0.3 \times 10^{6}$ of these cells with $1 \times 10^{6}$ irradiated $(12,000 \mathrm{rad}) \mathrm{MJ}$ tumor cells and $2 \times 10^{6}$ irradiated (3,000 rad) PBMC from DPw2 ${ }^{+}$donor Y2. Clone 8.7 was infected on one occasion and the resulting line named $8.7 \mathrm{H1}$; clone 8.8 was infected three times and the lines named $8.8 \mathrm{H} 1,8.8 \mathrm{H} 2$, and $8.8 \mathrm{H} 3$. The lines were fed every 4-5 $\mathrm{d}$ with media enriched with $15 \%$ IL-2. 8.7H1 and $8.8 \mathrm{H} 2$ were restimulated with irradiated (3,000 rad) $\mathrm{SB}^{+}{ }^{+}$PBMC every $8-11 \mathrm{~d}$, whereas $8.8 \mathrm{H} 1$ and $8.8 \mathrm{H} 3$ were not.

Prior to infection with HTLV-I, clones 8.7 and 8.8 were IL2 -dependent and required repeated stimulation with $\mathrm{DPw} 2^{+}$ cells. In the absence of antigenic stimulation, their growth slowed after $7 \mathrm{~d}$ and the cells died within $21 \mathrm{~d}$. With repeated antigenic stimulation, they grew well in culture for $\sim 45 \mathrm{~d}$ after the time that aliquots were taken for infection with HTLV-I; beyond this point, their growth slowed and they eventually died.

When these clones were exposed to MJ tumor cells, several changes were observed in their growth characteristics. In each case, their growth rate increased within 15 to $20 \mathrm{~d}$, and after 30 $\mathrm{d}$, increased cell clumping was observed. There was a partial loss of IL-2 dependence (cells could be maintained for $10 \mathrm{~d}$ without IL-2) although they never became completely IL-2 independent. Finally, the lines lost their requirement for repeated antigenic stimulation in order to grow.

Cytotoxic function of 8.7 and 8.8 prior to and following infection with HTLV-I. Before exposure to MJ tumor cells, clone 8.7 lysed DPw2 ${ }^{+}$M16B target cells (38 $45 \%$ lysis at 5:1 E:T ratio, mean $\pm \mathrm{SD}$ ), but failed to lyse DPw2- autologous F2B target cells (8 $\pm 4 \%$ lysis) (Fig. 1). 8.7H1 retained this cytotoxic function for $50 \mathrm{~d}$ in culture after exposure to HTLV-I, but then lost this activity over the next $25 \mathrm{~d}$ despite repeated stimulation with DPw2 ${ }^{+}$PBMC (Fig. 1).

Before infection with HTLV-I, clone 8.8 likewise lysed SB2 ${ }^{+}$ M16B target cells (mean $47 \pm 25 \%$ lysis at 5:1 E:T ratio in six separate determinations) but failed to lyse SB2- F2B target cells (4士6\% lysis) (Fig. 2). This cytotoxic activity was retained as long as the clone was maintained in culture. The three lines obtained after exposure of 8.8 to $\mathrm{MJ}$ tumor cells $(8.8 \mathrm{H} 1,8.8 \mathrm{H} 2$, and $8.8 \mathrm{H} 3$ ) each retained cytotoxic function for up to $70 \mathrm{~d}$, but then lost this activity. This loss of cytotoxic activity occurred both in the presence $(8.8 \mathrm{H} 2)$ and absence $(8.8 \mathrm{H} 1$ and $8.8 \mathrm{H} 3)$ of repeated antigenic stimulation with SB2 ${ }^{+}$PBMC. Lines $8.8 \mathrm{H} 1$ and $8.8 \mathrm{H} 3$ were HLA serotyped and each was found to express A1, A2, B7, $B 8, D R 2$, and DR4, identical to that of the original donor of the line (F2) but different from that of MJ-tumor cells (A1, B8, Cw6, Cw7, DR3, and DR7). Loss of cytotoxic function thus was not due to contamination with $\mathrm{MJ}$ tumor cells, and no additional 


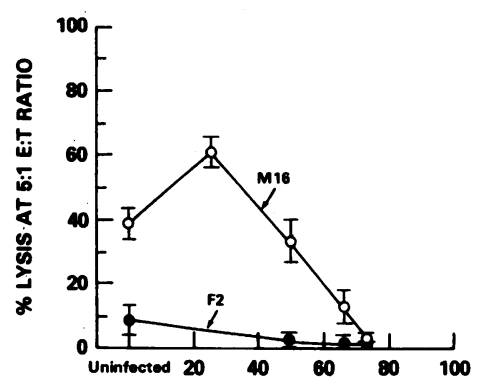

DAY FOLLOWING EXPOSURE TO HTLV-I
Figure 1. Cytotoxic function of clone 8.7 before and at various times following exposure to HTLV-I. Target cells were EBV-transformed lines from donor $\mathrm{M} 16\left(\mathrm{DPw} 2^{+}\right)(0)$ or F2 $\left(\mathrm{DPw} 2^{-}\right)(\bullet)$. Each point depicts the mean of triplicate determinations at a 5:1 E:T ratio; error bars depict \pm 1 SD.

HLA antigens were expressed following infection with HTLVI as has been reported in certain other cell lines $(19,20)$.

HTLV-I infected $T$ cell lines have been shown to proliferate in response to stimulator cells bearing any class II histocompatibility antigen (12), and we wondered if cytotoxic function might also become polyspecific. $8.8 \mathrm{H} 3$ was thus tested for cytotoxic activity against a variety of target lines (Table I). As can be seen, both before and 36 days after its exposure to HTLV-I, it lysed each of three DPw2 ${ }^{+}$targets (H9B, M16B, and Y2B),

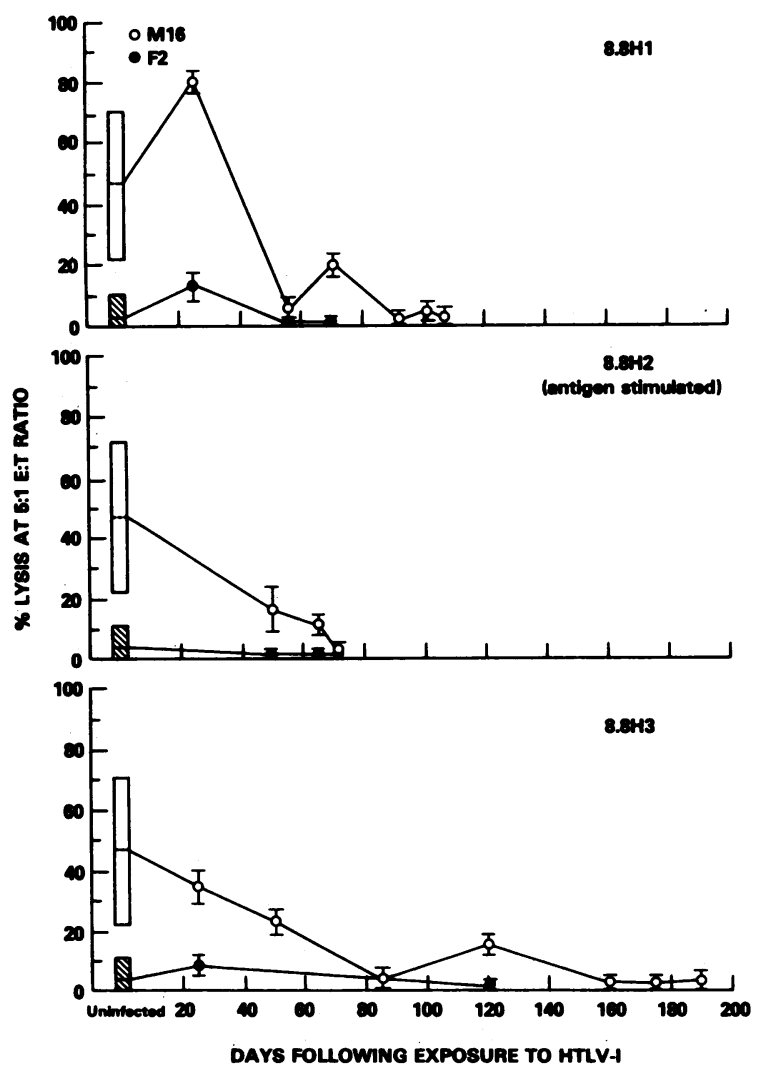

Figure 2. Cytotoxic function of clone 8.8 before exposure to HTLV-I and of three sublines $(8.8 \mathrm{H} 1,8.8 \mathrm{H} 2$, and $8.8 \mathrm{H} 3)$ at various times after exposure to HTLV-I. Subline $8.8 \mathrm{H} 2$ was repeatedly stimulated with DPw2-bearing PBMC, while $8.8 \mathrm{H} 1$ and $8.8 \mathrm{H} 3$ were not. Bars on the left show the mean \pm SD of six separate determinations of the cytotoxic function of 8.8 against EBV-transformed $B$ cell lines derived from donor M16 (DPw2 ${ }^{+}$) (clear bar) and F2 (DPw2 ${ }^{-}$) (shaded bar). Each point shows the mean of triplicate determination against the $B$ cell lines from M16 (0) or F2 (๑); error bars depict \pm 1 SD.

but failed to lyse any of four DPw2 ${ }^{-}$targets (F2B, FB6B, FB1 1B, and M14B) or the natural-killer cell sensitive line K562 (Table I). By day 120, when it had lost its activity against DPw2 ${ }^{+} \mathrm{M} 16 \mathrm{~B}$ cells, it also failed to lyse DPw2 ${ }^{+} \mathrm{Y} 2 \mathrm{~B}$ cells and again failed to lyse either DPw2- F2B cells or K562 target cells. Thus, neither the uninfected nor the infected line had natural killer activity, and $8.8 \mathrm{H} 3$ retained specificity for DPw2-bearing targets for at least $36 \mathrm{~d}$ after co-culture with MJ tumor cells (in the absence of further antigenic stimulation).

Evidence for HTLV-I infection by 8.7 and 8.8 following exposure to MJ tumor cells. Clones 8.7 and 8.8 were examined for expression of HTLV-I gag proteins p19 and p24 before infection both before and after co-culture with $\mathrm{MJ}$ tumor cells. Neither clone expressed any detectable p19 or p24 prior to infection; each line tested after exposure to MJ tumor cells, however, expressed viral gag protein on at least a proportion of the cells (Table II). In the case of line $8.8 \mathrm{H} 1$, however, only $10 \%$ of the cells were positive for p19 or p24 on day 36 (at a time when cytotoxic function was lost), and only faint expression of these proteins was noted. Because of this barely detectable expression of viral gag proteins, this line was further studied by Southern blot hybridization to determine whether it indeed contained HTLV-I provirus.

After digestion of DNA from line 8.8H1 (day 86) with Eco RI, which does not cleave within the HTLV-I genome (21), a single band of $\sim 9.5$ kilobase (kb) in length was obtained using the pCH-I ( $p X$-env plus pol) HTLV-I probe (Fig. 3). In contrast, no hybridization was observed to DNA from an EBV-transformed cord blood B cell line. This result indicates that $8.8 \mathrm{H} 1$ contained HTLV-I proviral DNA integrated in a monoclonal or oligoclonal fashion. Following digestion with Bam HI (which has two cleavage points within the genome of HTLV-I from patient MJ) (18), 5 bands were obtained at $\sim 1.0,3.4,6.6,8.0$, and $9.6 \mathrm{~kb}$. The $1.0-\mathrm{kb}$ band represents the internal proviral fragment bound by these two internal cleavage sites (18), and its presence indicates that there were no major deletions in this region of the provirus. The other bands represent unique integration sites and indicate that $8.8 \mathrm{H} 1$ contained the HTLV-I provirus integrated in an oligoclonal manner. Taken together, these results indicate that at least some cells in $8.8 \mathrm{Hi}$ were infected with HTLV-I in an oligoclonal fashion.

Investigation of the loss of cytotoxic function following $H T L V$ I infection. To further investigate the loss of cytotoxic function after HTLV-I infection, the ability of infected $8.8 \mathrm{HI}$ cells to suppress or block the cytotoxic function of uninfected 8.8 cells was studied. As shown in Fig. 4, a 10-fold excess of $8.8 \mathrm{H1}$ cells failed to suppress or block the ability of uninfected 8.8 cells to lyse M16B cells. MJ tumor cells similarly tested also failed to inhibit the function of 8.8 cells. Noncytotoxic $8.8 \mathrm{H} 1$ cells thus could not inhibit the cytotoxic function of 8.8 cells when added during the 4-h assay period.

Recent studies have indicated that the OKT3 surface antigen is coexpressed with the $T$ cell antigen receptor $(22,23)$, and OKT3 antibody has been shown to block the cytotoxic effector function of clone $8.8(13,14)$. In addition, Hoffman et al. (24) have recently found that the OKT3 murine hybridoma is lysed by cytotoxic $\mathrm{T}$ cells, presumably by the binding of OKT3 antibody on the surface of this hybridoma to the OKT3-T cell receptor complex. With this background, the ability of uninfected and HTLV-I infected 8.8 cells to lyse target cells expressing OKT3 antibody was studied. As shown in Fig. 5, cytotoxic ac- 


\begin{tabular}{|c|c|c|c|c|c|c|c|c|c|}
\hline \multirow[b]{3}{*}{ Target cell } & \multirow{2}{*}{\multicolumn{6}{|c|}{ HLA phenotype* }} & \multicolumn{3}{|c|}{ \% Lysis at 10:1 E:T ratioł } \\
\hline & & & & & & & \multicolumn{3}{|c|}{ Effector line } \\
\hline & $\mathbf{A}$ & B & $\mathrm{C}$ & DR & DQ & DP & 8.8 & $8.8 \mathrm{H} 3$ (day 36$)$ & $8.8 \mathrm{H} 3$ (day 190 ) \\
\hline H9B & 1,2 & 7,8 & 7 & 2,3 & $\mathrm{w} 1, \mathrm{w} 2$ & w1,w2 & 12 & 21 & ND§ \\
\hline M16B & 1,3 & 8,14 & - & 2,3 & $\mathrm{w} 1, \mathrm{w} 2$ & $w 1, w 2$ & 35 & 26 & 3 \\
\hline Y2B & 26,32 & 41,52 & 4 & 5,7 & w2,w3 & w1,w2 & 46 & 43 & 5 \\
\hline F2B & 1,2 & 7,8 & - & 2,4 & w1,w3 & w4,w5 & 0 & 1 & 2 \\
\hline FB6B & 25,31 & 15,40 & 3 & 4,4 & w3,- & w4,- & 2 & 4 & ND \\
\hline FB11B & 25,31 & 15,40 & 3 & 4,4 & w3,- & $\mathbf{w} 1,-$ & -1 & 2 & ND \\
\hline M14B & 1,3 & 8,14 & - & 2,3 & $w 1, w 2$ & w3,w4 & 1 & 2 & ND \\
\hline K562 & & & & & & & 1 & 2 & 6 \\
\hline
\end{tabular}

* EBV-transformed B cell lines used as targets were from donors with the listed HLA phenotypes. K562 is a natural killer cell-sensitive erythroid cell line. $\ddagger$ Results shown are the mean of triplicate determinations. Standard deviations were $\leqq 3 \%$ in all cases. $\S$ ND, Not done.

tivity against the OKT3 hybridoma was lost in parallel with the loss of cytotoxic activity against $\mathrm{DPw} 2^{+}$targets. In addition, while the uninfected 8.8 clone mediated $13.9 \pm 3.4 \%$ lysis of DPw2 ${ }^{-}$F2 cells in the presence of $20 \mu \mathrm{g} / \mathrm{ml}$ of Con A, late HTLVI-infected $8.8 \mathrm{H} 3$ cells failed to lyse F2 cells in the presence of Con A $(4.0 \pm 2.8 \%$ lysis). This loss of OKT3-directed lysis and of lectin-mediated cytoxicity suggested that the loss of cytotoxic activity after HTLV-I infection was not solely the result of an alteration of the antigen specificity of 8.8 , but instead involved a global loss of cytotoxic function. Possible mechanisms that might have been responsible for this loss were: $(a)$ a loss of surface antigens that could trigger cytotoxicity (including T3); and/or (b) a loss of the cytotoxic effector mechanism.

To test this first hypothesis, uninfected 8.8 cells that had been stimulated with DPw2 ${ }^{+}$cells 5 d previously, early (day 36 ) infected $8.8 \mathrm{H} 3$ cells that retained cytotoxic activity, and late (day 185) infected $8.8 \mathrm{H} 3$ cells that had lost their cytotoxic activity were examined for expression of T3, T4, T8, Leu 8, and IL-2 R. As seen in Fig. 6, 8.8 cells expressed T3 surface antigen $(83.8 \%$ positive, mean immunofluorescent intensity 469), and the expression of this antigen was unaffected or slightly increased in early $8.8 \mathrm{H} 3$ cells $(86.7 \%$ positive, mean immunofluorescent intensity 560). However, by day 185 , at a time that cytotoxic function was lost, there was a decrease in both the percentage of cells expressing $\mathrm{T} 3$ and the intensity of this expression $(47.4 \%$ positive, mean immunofluorescent intensity 334). Additional

Table II. Clones 8.7 and 8.8 Express HTLV-I p19 and p24 gag Proteins After Exposure to MJ Tumor Cells

\begin{tabular}{lcccc}
\hline Line & $\begin{array}{l}\text { Day after exposure } \\
\text { to MJ tumor cells }\end{array}$ & $\mathrm{p} 19$ (\% positive) & $\mathrm{p} 24$ (\% positive) & $\begin{array}{l}\text { Cytotoxic } \\
\text { function }\end{array}$ \\
\hline 8.7 & - & 0 & 0 & + \\
$8.7 \mathrm{H} 1$ & 71 & 30 & 33 & - \\
8.8 & - & 0 & 0 & + \\
$8.8 \mathrm{H} 1$ & 86 & 10 & 10 & - \\
$8.8 \mathrm{H} 3$ & 36 & 27 & 25 & + \\
$8.8 \mathrm{H} 3$ & 130 & 48 & 49 & - \\
& & & & \\
\hline
\end{tabular}

analysis showed that this decreased expression of T3 was observed both in cells that had been replenished with fresh IL-2-containing media the day before ( $54.0 \%$ positive, mean immunofluorescent intensity 373$)$ and cells that had been left in media for $5 \mathrm{~d}(50.7 \%$ positive, mean immunofluorescent intensity 376 ). In addition, the expression of $\mathrm{T} 3$ on these cells was not affected by stimulation with DPw2 ${ }^{+}$cells (results not shown).

In contrast to this decreased expression of $\mathrm{T} 3, \mathrm{~T} 4$ expression remained essentially unchanged following HTLV-I infection, and there was an increased expression of IL-2 R as has been reported by Leonard et al. (25) and Depper et al. (26) after HTLV-I infection. Unlike normal $T$ cell clones in which the expression of IL-2 $R$ is increased by exposure to antigen, the level of expression of IL-2 R by $8.8 \mathrm{H} 3$ was not affected by exposure to DPw $2^{+}$cells (90\% positive, mean immunofluorescent intensity 563 in unstimulated cells versus $92 \%$ positive, mean immunofluorescent

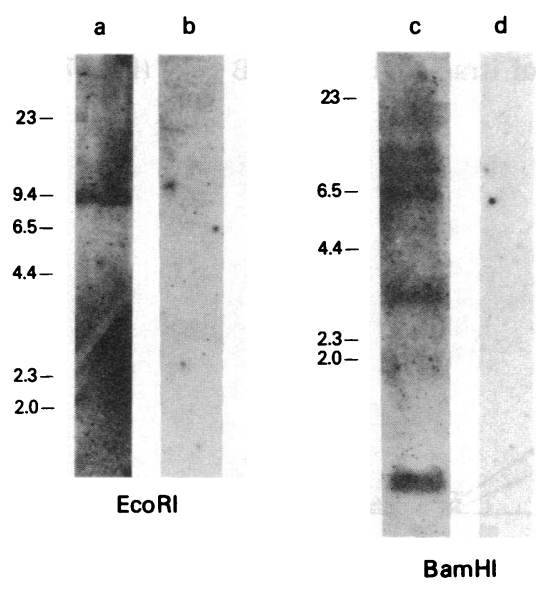

Figure 3. Detection of HTLV-I genome in $8.8 \mathrm{H} 1$ cells. Southern blot hybridization of high molecular weight DNA from $8.8 \mathrm{H} 1$ cells (lanes $a$ and $b$ ) or EBV-transformed cord B cells (lanes $c$ and $d$ ) following digestion with Eco RI (lanes $a$ and $b$ ) or Bam HI (lanes $c$ and $d$ ). Horizontal lines indicate (in kilobases) the positions of simultaneously assayed Hind III-digested fragments of $\lambda$-phage DNA used as a marker. 

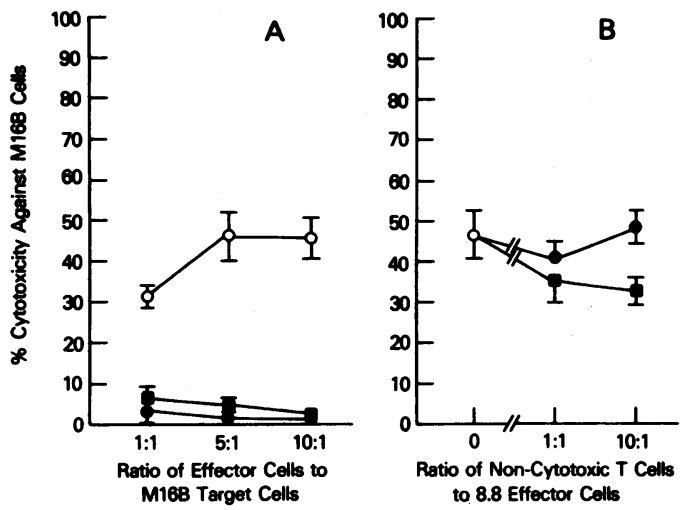

Figure 4. 8.8H1 cells (day 90) that have no cytotoxic function of their own fail to block the cytotoxic function of 8.8 cells when added during the cytotoxic assay period. $(A)$ Percent lysis of M16B target cells $(5,000)$ by 8.8 cells $(0), 8.8 \mathrm{H} 1$ cells on day $90(\bullet)$, or $\mathrm{MJ}$ tumor cells $(\square)$ at various $\mathrm{E}: \mathrm{T}$ ratios. $(B) 8.8 \mathrm{H} 1$ cells or $\mathrm{MJ}$ tumor cells were added during the 4-h ${ }^{51} \mathrm{Cr}$ release assay period to test their effect on the cytotoxic activity of 8.8 against M16B cells. Wells contained ${ }^{51} \mathrm{Cr}$-labeled M16B cells $(5,000), 8.8$ effector cells $(25,000)$ at a 5:1 E:T ratio, and either no added cells (0), or 25,000 or $250,0008.8 \mathrm{H} 1$ cells $(\bullet)$, or MJ tumor cells ( $(\mathbf{)}$.

intensity 659 in cells cultured with $\mathrm{DPw} 2^{+}$cells $5 \mathrm{~d}$ earlier). Neither the uninfected nor the HTLV-I infected cells expressed OKT8 or Leu 8 (result not shown). HTLV-I infection of 8.8 thus was associated with a decreased expression of T3 surface antigen and constitutively increased expression of IL-2 R.

Function of 8.8 in immunoglobulin production. The ability of clone 8.8 to provide help or suppressor activity for IgG production was studied both before and after infection with HTLVI. As shown in Fig. $7 A$, co-cultures of $5 \times 10^{4} 8.8$ cells with 5 $\times 10^{4}$ autologous (F2) B cells and $5 \times 10^{4}$ irradiated (3,000 rad) $\mathrm{DPw}^{+} \mathrm{Y} 2 \mathrm{~B}$ cells as a source of DPw2-alloantigen produced $1,210 \times / \div 1.01 \mathrm{ng} / \mathrm{ml}$ of $\mathrm{IgG}$. This IgG production required the presence of both 8.8 cells and the DPw $2^{+}$cells. When early (day 36) HTLV-I infected $8.8 \mathrm{H} 3$ cells were studied in a similar manner, IgG production by F2 B cells was obtained both in the presence and absence of irradiated DPw $2^{+} \mathrm{B}$ cells (Fig. $7 A$ ).

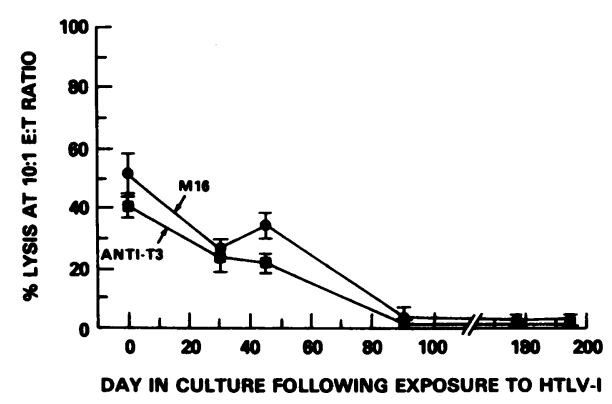

Figure 5. Loss of cytotoxic function against anti-T3 bearing targets parallels the loss of cytotoxic function against DPw2-bearing B cells. Clone 8.8 was tested for cytotoxic activity against an EBV-transformed B cell line from donor M16 (DPw2 $\left.{ }^{+}\right)(\bullet)$ and against the antiT3-antibody producing hybridoma $(\boldsymbol{\theta})$ before and at various times after infection with HTLV-I (subline 8.8H3). Each point depicts the mean \pm SD of triplicate determinations at a 10:1 E:T ratio.
Late (day 186) $8.8 \mathrm{H} 3$ cells that had lost their cytotoxic function similarly provided constitutive help for nonspecific IgG production in the presence or absence of irradiated DPw2 ${ }^{+} \mathrm{B}$ cells; the help provided by these late $8.8 \mathrm{H} 3$ cells was comparable to that provided by the antigen-stimulated uninfected 8.8 cells but somewhat less than observed with the early infected $8.8 \mathrm{H} 3$ cells. This help was not an artifact due to mycoplasma contamination as the lines were tested for mycoplasma by a variety of techniques and consistently found to be negative. Late infected $8.8 \mathrm{H} 3$ cells could also provide help for DPw2 ${ }^{+}$Y 2 B cells, but the supernatant of these cells was unable to mediate this help (Table III) and in addition had no detectable IL-2 (as assayed using the IL2 sensitive HT-2 line [11]). Neither uninfected 8.8 cells, early infected $8.8 \mathrm{H} 3$ cells, or late infected $8.8 \mathrm{H} 3$ cells $\left(5 \times 10^{4}\right)$ suppressed IgG production when added to $P W M$-stimulated cultures of $5 \times 10^{4} \mathrm{~F} 2 \mathrm{~B}$ cells and $1.0 \times 10^{5}$ irradiated (2,000 rad) F2 T cells (Fig. $7 \mathrm{~B}$ ) but rather resulted in an increase in IgG production. Thus, the OKT4 ${ }^{+}$cytotoxic clone 8.8 could provide help for nonspecific IgG production when stimulated with DPw2 antigen, and following HTLV-I infection, this helper function became independent of DPw2 antigen stimulation. This constitutive helper function remained even at a time when the line had lost its cytotoxic activity.

\section{Discussion}

This study demonstrates that an $\mathrm{OKT} 4^{+} \mathrm{T}$ cell clone could simultaneously manifest both specific cytotoxic activity against allogenic targets and help for nonspecific IgG production by autologous B cells when stimulated with the appropriate alloantigen, and that these two functions were differentially affected following infection with HTLV-I. Cytotoxic function was preserved for up to $70 \mathrm{~d}$ but was then lost, and this loss was associated with a decreased expression of T3 surface antigen. Help for IgG production became independent of DPw2 antigenic stimulation early after infection with HTLV-I, and this constitutive help remained after the cytotoxic function was lost.

While cytotoxic function was eventually lost in these lines, it was preserved with unchanged specificity at least up to $36 \mathrm{~d}$ after exposure to MJ tumor cells (Table I) even without additional antigenic stimulation. During this initial period, the clones proliferated rapidly $\left(8.8 \mathrm{H} 3\right.$ expanded from $0.3 \times 10^{6}$ cells at the time of HTLV-I exposure to $86 \times 10^{6}$ cells on day 25). This ability to expand a clone with defined cytotoxic activity might potentially have application in such areas as cellular HLA typing (for example of antigens not resolved by available antisera) or the biochemical study of $T$ cell receptor structures; such an approach would particularly be useful in cases where the stimulator antigens were difficult to obtain or where the untransformed clone grew poorly. It should be stressed, however, that the use of such transformed clones should only be undertaken with appropriate biohazard containment and with an awareness of the potential alterations in $\mathrm{T}$ cell functions that may be induced by HTLV-I.

After this initial period, clones 8.7 and 8.8 eventually lost their cytotoxic function. A similar loss of function of two cytotoxic clones after transformation with HTLV-I has been observed by Popovic et al. (9). In the case of 8.7 and 8.8 , this loss occurred despite repeated antigenic stimulation, suggesting that a lack of antigenic exposure was not the cause of the loss of function. 
T3
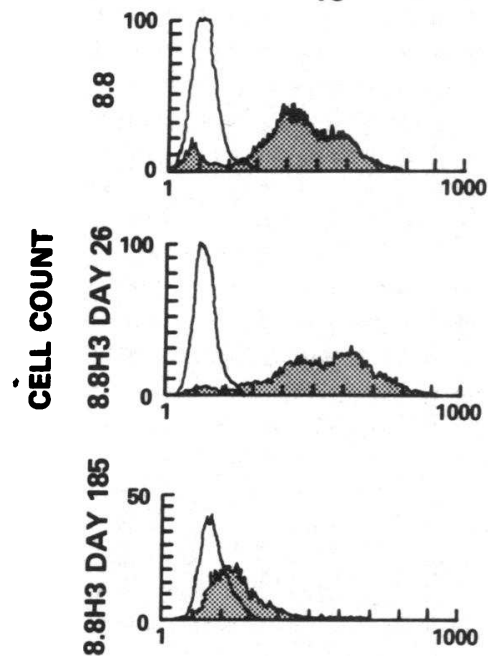

T4
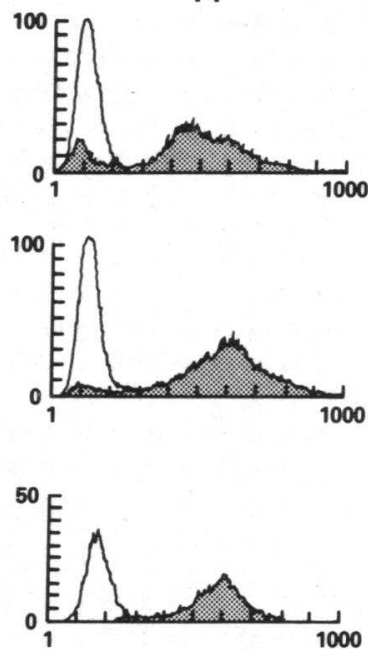

LOG FLUORESCENCE
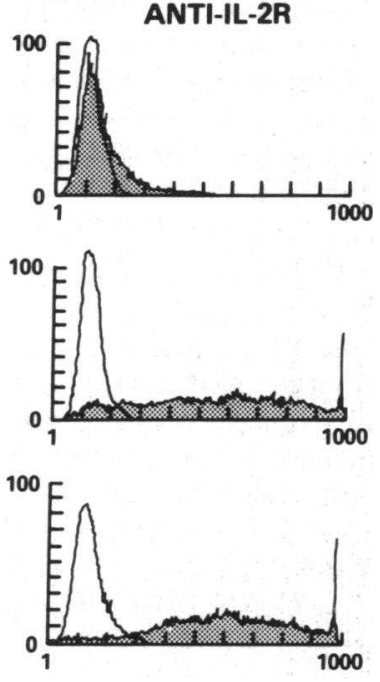

Figure 6. Expression of T3, T4, and IL-2 $R$ surface antigen by 8.8 , early (day 26) $8.8 \mathrm{H} 3$ cells, and late (day 185) $8.8 \mathrm{H} 3$ cells as analyzed by FACS. Clear areas depict the control with no antibody, while the shaded areas depict the result with the fluorescent-conjugated antibody.
Cell-mediated lysis can be divided into two steps: (a) target cell binding and conjugate formation, and $(b)$ delivery of the lethal hit (13). The cytotoxic activity of clone 8.8 has been shown to be blocked by low concentrations of OKT4 or OKT3 antibody (13). T4 surface antigen is believed to function as a second mechanism for binding between $\mathrm{T}^{+}$effector cells and class II HLA antigen-bearing target cells (particularly when the affinity
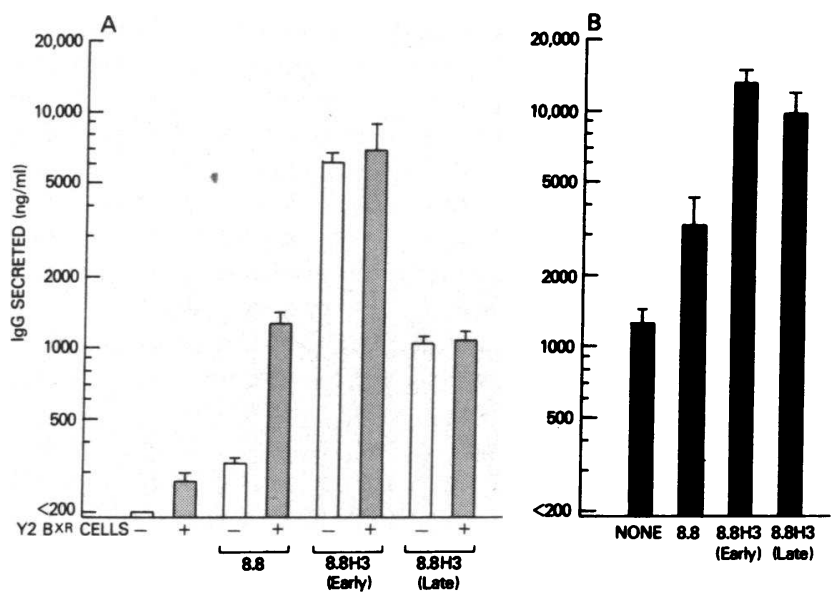

Figure 7. (A) Ability of HTLV-I uninfected and infected 8.8 cells to provide help for IgG antibody production by autologous (F2) B cells. Cultures contained $5 \times 10^{4} \mathrm{~F} 2$ B cells; either no $\mathrm{T}$ cells or $5 \times 10^{4} 8.8$, early (day 26) $8.8 \mathrm{H} 3$ cells, or late (day 186 ) $8.8 \mathrm{H} 3$ cells; and either no or $5 \times 10^{4}$ irradiated $(3,000 \mathrm{rad}) \mathrm{Y} 2\left(\mathrm{DPw} 2^{+}\right) \mathrm{B}$ cells as a source of DPw2 alloantigen. Cumulative IgG produced was measured in 10-d supernatants. Results shown are the mean $X / \div$ SD of triplicate cultures. No detectable IgG was produced by cultures containing only 8.8 cells, early or late $8.8 \mathrm{H} 3$ cells, or irradiated $(3,000 \mathrm{rad})$ Y2 B cells. $(B)$ Failure of HTLV-I uninfected of infected 8.8 cells to suppress PWMinduced IgG production by autologous cells. To cultures containing 5 $\times 10^{4} \mathrm{~F} 2 \mathrm{~B}$ cells, $1 \times 10^{5}$ irradiated (2,000 rad) F2 T cells, and PWM $1: 100$ (vol/vol) were added either no additional cells (none), $5 \times 10^{4}$ 8.8 cells, $5 \times 10^{4}$ early (day 26 ), or $5 \times 10^{4}$ late (day 186$) 8.8 \mathrm{H} 3$ cells. Results shown are the mean $X / \div$ SD IgG produced in $10 \mathrm{~d}$ in triplicate cultures. of binding by the $\mathrm{T}$ cell receptor is low) $(13,14)$. T3 surface antigen has been shown to be coexpressed with the $T$ cell antigen receptor $(22,23)$, and binding to this complex (as by target cells bearing OKT3 antibody) appears to be sufficient to trigger the cytotoxic effector mechanism (24).

Clone 8.8 expressed unchanged levels of T4 surface antigen at a time when it had lost its cytotoxic function, indicating that the loss of function was not due to a failure to express this surface glycoprotein. Expression of T3 surface antigen, however, was considerably decreased, loss of cytotoxic activity against OKT3bearing cells was lost in parallel with loss of activity against DPw2-bearing targets, and late $8.8 \mathrm{H} 3$ cells failed to mediate cytotoxic function in the presence of Con A. These results argue against a change in antigen specificity of 8.8 (e.g., by point mutations of the $T$ cell receptor) as causing the loss of function, and suggest instead that there was a general loss of cytotoxic function. One possible mechanism for this loss might have been the decreased expression of the T3-antigen receptor complex (or other surface receptors that might mediate cytotoxicity) in these cells. Alternatively, HTLV-I infection may interfere with the cytotoxic effector mechanism. It should be noted that alterations in antigen-specific $T$ cell function (specifically a loss of tetanus-

Table III. Supernatant of $8.8 \mathrm{H} 3$ Cells Does Not Provide Help for Immunoglobulin Production

\begin{tabular}{ll}
\hline Stimuli added to Y2 B cells $\left(5 \times 10^{4}\right)$ & IgG produced \\
\hline & $n g / m l$ \\
None & $<100^{*}$ \\
Y2 T cells $\left(1 \times 10^{5}\right)+\mathrm{PWM}$ & $1,050(1.42)$ \\
$8.8 \mathrm{H} 3$ (late) cells $\left(5 \times 10^{4}\right)$ & $489(1.23)$ \\
$8.8 \mathrm{H} 3$ (late) supernatant $\ddagger$ & $<100$
\end{tabular}

* Geometric mean of triplicate cultures (SEM).

‡ Late 8.8H3 cells were washed three times, cultured for $48 \mathrm{~h}$ in RPMI-1640 medium supplemented with $10 \%$ FCS at $1 \times 10^{6} / \mathrm{ml}$, and the supernatant filtered through a $0.45-\mu \mathrm{m}$ filter. This supernatant was - added at a final dilution of 1:4. 
toxoid-induced proliferation) have been observed after HTLV$I$ infection without a decrease in T3 expression (H. Mitsuya et al., unpublished observation), and this should thus not be viewed as the only mechanism for the loss of antigen-specific function following HTLV-I infection. It is possible that this is one of several mechanisms, or alternately that both the loss of antigenspecific function and the decreased expression of $\mathrm{T} 3$ are secondary to an underlying alteration (for example, decreased or altered production of the $\mathrm{T}$ cell antigen receptor). Preliminary results studying the $T$ cell receptor beta chain in clones infected with HTLV-I have failed to demonstrate alterations in rearrangement and revealed only slightly decreased levels of beta chain messenger RNA (mRNA) production (R. F. Jarrett et al., personal communication; H. Mitsuya et al., unpublished observation), but as yet untested alterations may be involved.

Similar to the present results, leukemic $\mathrm{T}$ cells from patients with ATL have recently been described by Tsuda and Takatsuki (27) and by Morimoto et al. (28) to have decreased or absent expression of T3 antigen. The decreased expression of T3 in culture observed here may be a model for these leukemic cells, and suggests that the ATL cells do not necessarily develop from normal cells with decreased $\mathrm{T} 3$ expression but rather, that this may be a consequence of HTLV-I infection.

Unlike the cytotoxic function of clone 8.8 , which was lost after HTLV-I infection, helper function for nonspecific IgG production became independent of antigenic stimulation by DPw2bearing cells soon after exposure to $\mathrm{MJ}$ tumor cells, and the cells retained this constitutive helper function even when cytotoxic function was lost. Similar constitutive help for Ig production has been observed in a keyhole limpet hemocyanin-specific $T$ cell clone infected with HTLV-I $(9,11)$. In contrast, OKT4 ${ }^{+}$ leukemic cells from patients with ATL generally do not provide help for Ig and instead manifest suppressor function or induce it in other cells (28-31). It has been hypothesized that this suppression may be a result of the high level of IL-2 $R$ expression absorbing IL-2 from the culture medium; the failure to observe suppression by $8.8 \mathrm{H} 3$ argues against this mechanism. Sodroski et al. (32) have recently shown that HTLV-I induces a transactivating factor (presumably encoded by the long open reading frame (LOR) in the pX region of the HTLV-I genome) which increases transcription of HTLV-I genes. Preliminary studies at the molecular level of the increased expression of IL-2 $R$ in HTLV-I infected cells have failed to find alterations in IL-2 gene organization or of mRNA processing, and have instead suggested that this increased expression is due to gene deregulation, possibly mediated by the LOR protein (33). It has been postulated that other $\mathrm{T}$ cell genes may similarly be activated by a product of the HTLV-I genome (most likely the LOR protein) (32), and it is possible that the constitutive help observed after HTLV-I infection may be the result of the trans-activation of certain $\mathrm{T}$ cell products. The failure of the supernatant of $8.8 \mathrm{H} 3$ to provide help suggests that direct $\mathrm{T}$ cell contact may be required for this helper activity, or that it may be mediated by a factor that is either labile or produced in small amounts.

The present results also have implications in the pathogenesis of leukemia in persons infected with HTLV-I. Immunologic defense mechanisms, particularly $T$ cell-mediated cytolysis, are considered to play an important role in the surveillance against virally induced tumors $(34,35)$, and the ability to evade these defenses is associated with increased viral oncogenicity. Strain 12 of adenovirus, for example, inhibits the expression of class I histocompatibility antigens by infected cells and thus enables them to escape detection by cytotoxic T cells (36). Moreover, experiments with recombinant plasmids have indicated that this property is associated with increased oncogenicity in immunocompetent animals (37). In the case of HTLV-I, while the virus is acutely transforming in vitro, only $1-2 \%$ of infected individuals eventually develop leukemia-lymphoma, suggesting that in most persons there is immunologic control of these transformed $T$ cells. As evidence for this control, cytotoxic $\mathrm{T}$ cell lines specific for HTLV-I have been derived from asymptomatic carriers of ATL (38), from a patient with ATL unusually responsive to therapy (39), and from a fraction of patients with ATL who have been brought into partial remission (40).

The results of this study provide a model by which cytotoxic T cells specific for HTLV-I may lose their cytotoxic function as a result of contact with HTLV-I-producing target cells and subsequent infection with this virus; this loss of function may in turn be permissive for the development of ATL. While the cytotoxic clones studied here were alloreactive and OKT4 ${ }^{+}$, a similar loss of cytotoxic function has been observed in an HTLV-I infected OKT ${ }^{+}$HTLV-I specific T cell clone (41). This observation has implications in the treatment of patients with ATL or a prodrome of ATL. Measures that block the infection of cytotoxic T cells by HTLV-I (such as the administration of a reverse transcriptase inhibitor) might enhance the immunologic control of transformed $\mathrm{T}$ cells and aid in the treatment or prevention of this disease.

\section{Acknowledgments}

The authors thank Mary Megson and Sandra E. Pike for their technical help and Roy Overton for doing the flow cytometry studies. In addition, we wish to thank William E. Biddison, J. Stephen Shaw, and David L. Nelson for their helpful comments.

This project has been funded at least in part with federal funds from the Department of Health and Human Services under contract N01-CO23910 with Program Resources, Inc. The contents of this publication do not necessarily reflect the views or policies of the Department of Health and Human Services, nor does the mention of trade names, commercial products, or organizations imply endorsement by the United States Government.

\section{References}

1. Poiesz, B. J., F. W. Ruscetti, A. F. Gazdar, P. A. Bunn, J. D. Minna, and R. C. Gallo. 1980. Detection and isolation of type C retroviral particles from fresh and cultured lymphocytes of a patient with cutaneous T-cell lymphoma. Proc. Natl. Acad. Sci. USA. 77:7415-7419.

2. Yoshida, M., I. Miyoshi, and Y. Hinuma. 1982. Isolation and characterization of retrovirus from cell lines of human adult T-cell leukemia and its implication in the disease. Proc. Natl. Acad. Sci. USA. 79: 2031-2035.

3. Popovic, M., P. S. Sarin, M. Robert-Guroff, V. S. Kalyanaraman, D. Mann, J. Minowada, and R. C. Gallo. 1983. Isolation and transmission of human retrovirus (human T-cell leukemia virus). Science (Wash. DC). 219:856-859.

4. Robert-Guroff, M., Y. Nakao, K. Notake, Y. Ito, A. Sliski, and R. C. Gallo. 1982. Natural antibodies to human retrovirus HTLV in a cluster of Japanese patients with adult T cell leukemia. Science (Wash. DC). 215:975-978.

5. Bunn, P. A., G. P. Schechter, E. Jaffe, D. Blayney, R. C. Young, M. J. Matthews, W. Blattner, S. Broder, M. Robert-Guroff, and R. C. Gallo. 1983. Clinical course of retrovirus-associated adult T-cell lymphoma in the United States. N. Engl. J. Med. 309:257-264.

6. Essex, M. E., M. F. McLane, N. Tachibana, D. P. Francis, and T. H. Lee. 1984. Seroepidemiology of human T-cell leukemia virus in relation to immunosuppression and the acquired immunodeficiency syndrome. In Human T-Cell Leukemia/Lymphoma Virus. R. C. Gallo, M. E. Essex, and L. Gross, editors. Cold Spring Harbor Laboratory, Cold Spring Harbor. 355-362. 
7. Miyoshi, I., I. Kubonishi, S. Yoshimoto, T. Akagi, Y. Ohtsuki, Y. Shiraishi, K. Nagata, and Y. Hinuma. 1981. Type C particles in a cord T-cell line derived by co-cultivating normal human cord lymphocytes and human leukaemic cells. Nature (Lond.). 294:770-771.

8. Mitsuya, H., H. G. Guo, J. Cossman, M. Megson, M. S. Reitz, Jr., and S. Broder. 1984. Functional properties of antigen-specific $T$ cells infected by human T-cell leukemia-lymphoma virus (HTLV-I). Science (Wash. DC). 225:1484-1486.

9. Popovic, M., N. Flomenberg, D. J. Volkman, D. Mann, A. S. Fauci, B. Dupont, and R. C. Gallo. 1984. Alteration of T-cell functions by infection with HTLV-I or HTLV-II. Science (Wash. DC). 226:459462.

10. Salahuddin, S. Z., P. D. Markham, S. G. Lindner, J. Gootenberg, M. Popovic, H. Hemmi, P. S. Sarin, and R. C. Gallo. 1984. Lymphokine production by cultured human $\mathrm{T}$ cells transformed by human $\mathrm{T}$ cell leukemia-lymphoma virus-I. Science (Wash. DC). 223:703-707.

11. Volkman, D. J., M. Popovic, R. C. Gallo, and A. S. Fauci. 1985. Human $T$ cell leukemia/lymphoma virus-infected antigen-specific $T$ cell clones: Indiscriminant helper function and lymphokine production. $J$. Immunol. 134:4237-4243.

12. Suciu-Foca, N., P. Rubenstein, M. Popovic, R. C. Gallo, and D. W. King. 1984. Reactivity of HTLV-transformed human T-cell lines to MHC class II antigens. Nature (Lond.). 312:275-277.

13. Biddison, W. E., P. E. Rao, M. A. Talle, G. Goldstein, and S. Shaw. 1984. Possible involvement of the T4 molecule in T cell recognition of class III HLA antigens. Evidence from studies of CTL-target binding. J. Exp. Med. 159:783-797.

14. Shaw, S., G. Goldstein, T. A. Springer, and W. E. Biddison. 1985. Susceptibility of cytotoxic T lymphocyte (CTL) clones to inhibition by anti-T3 and anti-T4 (but not anti-LFA-1) monoclonal antibodies varies with the "avidity" of CTL-target interaction. J. Immunol. 134:30193026.

15. Tosato, G., I. T. Magrath, and R. M. Blaese. 1982. T cell-mediated immunoregulation of Epstein Barr virus- (EBV) induced B lymphocyte activation in EBV-seropositive and EBV-seronegative individuals. J. Immunol. 128:575-579.

16. Yarchoan, R., H. S. Schneider, B. B. Wray, and D. L. Nelson. 1983. Specific anti-influenza virus antibody production in vitro by lymphocytes from a subset of patients with hypogammaglobulinemia. $J$. Clin. Invest. 71:1720-1727.

17. Robert-Guroff, M., F. W. Ruscetti, L. E. Posner, B. J. Poiesz, and R. C. Gallo. 1981. Detection of the human T cell lymphoma virus p19 in cells of some patients with cutaneous T cell lymphoma and leukemia using a monoclonal antibody. J. Exp. Med. 154:1957-1964.

18. Manzari, V., F. Wong-Staal, G. Franchini, S. Columbini, E. P. Gelmann, S. Orozlan, S. Staal, and R. C. Gallo. 1983. Human T-cell leukemia-lymphoma virus (HTLV): Cloning of an integrated defective provirus and flanking cellular sequences. Proc. Natl. Acad. Sci. USA. 80: 1574-1578.

19. Mann, D. L., M. Popovic, P. Sarin, C. Murray, M. S. Reitz D. M. Strong, B. F. Haynes, R. C. Gallo, and W. A. Blattner. 1983. Cell lines producing human T-cell lymphoma virus show altered HLA expression. Nature (Lond.). 305:58-60.

20. Clarke, M. F., E. P. Gelmann, and M. S. Reitz, Jr. 1983. Homology of human T-cell leukemia virus envelope gene with class I HLA gene. Nature (Lond.). 305:60-62.

21. Wong-Staal, F., B. Hahn, V. Manzari, S. Columbini, G. Franchini, E. P. Gelmann, and R. C. Gallo. 1983. A survey of human leukaemias for sequences of a human retrovirus. Nature (Lond.). 302:626-628.

22. Meuer, S. C., O. Acuto, R. E. Hussey, J. C. Hodgdon, K. A. Fitzgerald, S. F. Schlossman, and E. L. Reinherz. 1983. Evidence for the T3-associated $90 \mathrm{~K}$ heterodimer as the T-cell antigen receptor. Nature (Lond.). 303:808-810.

23. Weiss, A., and J. D. Stobo. 1984. Requirement for the coexpression of $\mathrm{T} 3$ and the $\mathrm{T}$ cell antigen receptor on a malignant human $\mathrm{T}$ cell line. J. Exp. Med. 160:1284-1299.

24. Hoffman, R. W., J. A. Bluestone, O. Leo, and S. Shaw. 1985. Lysis of anti-T3 bearing murine hybridoma cells by human allospecific cytotoxic $\mathrm{T}$ cell clones and inhibition of that lysis by anti-T3 and antiLFA-1 antibodies. J. Immunol. 135:5-9.

25. Leonard, W. J., J. M. Depper, T. Uchiyama, K. A. Smith, T. A. Waldmann, and W. C. Greene. 1982. A monoclonal antibody that appears to recognise the receptor for human T-cell growth factor; partial characterization of the receptor. Nature (Lond.). 300:267-269.

26. Depper, J. M., W. J. Leonard, M. Krönke, T. A. Waldmann, and W. C. Greene. 1984. Augmented T cell growth factor receptor expression in HTLV-I infected human leukemic T cells. J. Immunol. 133:1691-1695.

27. Tsuda, H., and K. Takatsuki. 1984. Specific decrease in T3 antigen density in adult T-cell leukaemia cells: I. Flow microfluorometric analysis. Br. J. Cancer. 50:843-845.

28. Morimoto, C., T. Matsuyama, C. Oshige, H. Tanaka, T. Hercend, E. Reinherz, and S. F. Schlossman. 1985. Functional and phenotypic studies of Japanese adult T cell leukemia cells. J. Clin. Invest. 75:836843.

29. Uchiyama, T., K. Sagawa, K. Takatsuki, and H. Uchino. 1978. Effect of adult T-cell leukemia cells on pokeweed mitogen-induced normal B-cell differentiation. Clin. Immunol. Immunopathol. 10:24-34.

30. Yamada, Y. 1983. Phenotypic and functional analysis of leukemic cells from 16 patients with adult T-cell leukemia/lymphoma. Blood. 61: 192-199.

31. Waldmann, T. A., W: C. Greene, P. S. Sarin, C. Saxinger, D. W. Blayney, W. A. Blattner, C. K. Goldman, K. Bongiovanni, S. Sharrow, J. M. Depper, W. Leonard, T. Uchiyama, and R. C. Gallo. 1984. Functional and phenotypic comparison of human $\mathrm{T}$ cell leukemia/ymphoma virus positive adult $\mathrm{T}$ cell leukemia with human $\mathrm{T}$ cell leukemia/lymphoma virus negative Sézary leukemia, and their distinction with antiTac monoclonal antibody identifying the human receptor for $\mathrm{T}$ cell growth factor. J. Clin. Invest. 73:1711-1718.

32. Sodroski, J. G., C. A. Rosen, and W. A. Haseltine. 1984. Transacting transcriptional activation of the long terminal repeat of human T lymphotropic viruses in infected cells. Science (Wash. DC). 225:381385.

33. Krönke, M., W. J. Leonard, J. M. Depper, and W. C. Greene. 1985. Deregulation of interleukin-2 receptor gene expression in HTLVI-induced adult T-cell leukemia. Science (Wash. DC). 228:1215-1217.

34. Klein, G. 1980. Immune and non-immune control of neoplastic development: Contrasting effects of host and tumor evolution. Cancer (Phila.). 45:2486-2499.

35. Britt, W. J., and B. Chesebro. 1983. H-2D control of recovery from Friend virus leukemia: $H-2 D$ region influences the kinetics of the T lymphocyte response to Friend virus. J. Exp. Med. 157:1736-1745.

36. Schrier, P. I., R. Bernards, R. T. M. J. Vaessen, A. Houweling, and A. J. van der Eb. 1983. Expression of class I major histocompatibility antigens switched off by highly oncogenic adenovirus 12 in transformed rat cells. Nature (Lond.). 305:771-775.

37. Bernards, R., P. I. Schrier, A. Houweling, J. L. Bos, A. J. van der Eb, M. Zijlstra, and C. J. M. Melief. 1983. Tumorigenicity of cells transformed by adenovirus type 12 by evasion of $\mathrm{T}$ cell immunity. Nature (Lond.). 305:776-779.

38. Kannagi, M., K. Sugamura, H. Sato, K. Okochi, H. Uchino, and Y. Hinuma. 1983. Establishment of human cytotoxic $T$ cell lines specific for human adult T cell leukemia virus-bearing cells. J. Immunol. 130: 2942-2946.

39. Mitsuya, H., L. A. Matis, M. Megson, P. A. Bunn, C. Murray, D. L. Mann, R. C. Gallo, and S. Broder. 1983. Generation of an HLArestricted cytotoxic $T$-cell line reactive against cultured cells from a patient infected with human T-cell leukemia/lymphoma virus (HTLV). J. Exp. Med. 158:994-998.

40. Kannagi, M., K. Sugamura, K. I. Kinoshita, H. Uchino, and Y. Hinuma. 1984. Specific cytolysis of fresh tumor cells by an autologous killer cell line derived from an adult $\mathrm{T}$ cell leukemia/lymphoma patient. J. Immunol. 133:1037-1041.

41. Mitsuya, H., H. G. Guo, M. Megson, C. Trainor, M. S. Reitz, Jr., and S. Broder. 1984. Transformation and cytopathogenic effect in an immune human T-cell clone infected by HTLV-I. Science (Wash. DC). 223:1293-1296. 